Tạp chi Công nghệ Sinh học 14(1): 63-73, 2016

\title{
SOMATIC EMBRYOGENESIS FROM LEAF TRANSVERSE THIN CELL LAYER DERIVED-CALLUS OF VIETNAMESE GINSENG (PANAX VIETNAMENSIS HA ET GRUSHV.)
}

\author{
Vu Thi Hien, Nguyen Phuc Huy, Bui Van The Vinh, Hoang Xuan Chien, Hoang Thanh Tung, Nguyen \\ Ba Nam, Vu Quoc Luan, Duong Tan Nhut
}

Tay Nguyen Institute for Scientific Research, Vietnam Academy of Science and Technology

Received: 23.3.2015

Accepted: 30.8 .2015

\section{SUMMARY}

No report on plant regeneration via somatic embryogenesis of $P$. vietnamensis has been previously published. In the present study, somatic embryogenesis via callus formation from cultures of leaf transverse thin cell layers (tTCLs) of Vietnamese ginseng (Panax vietnamensis Ha et Grushv.) was investigated. $\alpha$-naphthaleneacetic acid (NAA), 2,4-dichlorophenoxyacetic acid (2,4-D), 6-benzylaminopurine (BA) and thidiazuron (TDZ) were added separately and in combination into the culture media. Explant necrosis or low callogenesis rates were observed when 1-mm wide leaf tTCLs were cultured on media with TDZ, BA, 2,4-D or NAA. On the other hand, calli were successfully induced from the tTCL explants cultured on medium supplemented with either 2,4-D and BA or 2,4$\mathrm{D}$ and TDZ. Callogenesis was observed under both light and dark conditions. The highest callogenesis rate $(100 \%)$ was obtained on Murashige and Skoog (MS) basal medium supplemented with $1.0 \mathrm{mg} \mathrm{l}^{-1}$ 2,4-D in combination with $0.1 \mathrm{mg}^{-1} \mathrm{TDZ}$ in darkness after eight weeks of culture. White calli were cut into small pieces $\left(1.0 \times 1.0 \mathrm{~cm}\right.$ dimension) and placed on MS media containing $1.0 \mathrm{mg}^{-1} 2,4-\mathrm{D}, 0.5 \mathrm{mg} \mathrm{l}^{-1} \mathrm{NAA}$ and TDZ at various concentrations $\left(0.01 ; 0.1 ; 0.2 ;\right.$ and $\left.0.5 \mathrm{mg} \mathrm{l}^{-1}\right)$, and the best callus proliferation was recorded on medium containing $1.0 \mathrm{mg} \mathrm{l}^{-1}$ 2,4-D and $0.2 \mathrm{mg} \mathrm{l}^{-1}$ TDZ. Somatic embryogenesis, with a success rate of $53.3 \%$ and 35 embryos per explant, was achieved when calli were subcultured onto MS medium supplemented with $1.0 \mathrm{mg}^{-1}$ 2,4-D, $0.5 \mathrm{mg} \mathrm{l}^{-1} \mathrm{NAA}$ and $0.2 \mathrm{mg}^{-1} \mathrm{TDZ}$.

Keywords: Callogenesis, Panax vietnamensis, somatic embryos, thin cell layers

\section{INTRODUCTION}

Ginseng is a medicinal herb that has long been used in the Far East (Eleutherococcus senticosus), America (Panax quinquefolius), and in particular Korea and China (Panax ginseng) as a respected herbal medicine in maintaining physical vitality. Vietnamese ginseng (Panax vietnamensis $\mathrm{Ha}$ et Grushv., 1985) was found in the central highlands of Vietnam in 1973, and was regarded as a new species belonging to the genus Panax.

Investigations of the metabolite constituents of $P$. vietnamensis have identified various chemical constituents including 49 saponins, in which 25 saponins are common to other Panax species and 24 new saponins are unique for $P$. vietnamensis, named vina-ginsenoside $R_{1}$ to $R_{24}$. In addition, an extremely high concentration of ocotillol saponins is present, and in particular, majonoside- $\mathrm{R}_{2}$ ocupies $5.3 \%$ of the dried rhizome weight (Duc et al., 1999). The main active compounds of $P$. vietnamensis are ginsenosides (Yamasaki, 2000), which have a variety of beneficial effects, including free radical scavenging (Huong et al., 1998), anticancer effects (Konoshima et al., 1999) and suppressive effects of psychological stress (Yobimoto et al., 2000).

The current supply of $P$. vietnamensis is fleeting and this has been attributed to the plant's narrow habitat range, slow growth rate and over-harvesting. Therefore, $P$. vietnamensis has been designated an endangered species (red Data Book of Vietnam, 1996).

One of the most practical and efficient ways to solve the current supply dilemma is to produce plantlets in vitro on a large-scale. Our previous report, however, showed that in vitro propagation of this species is still limited due to the complicated transplantation process and low survival rate of plantlets after being transferred to ex vitro conditions (Nhut et al., 2010). 
Somatic embryogenesis is used as a tool for micropropagation of herbaceous plants, including ginseng (Monteiro et al., 2002). There have been a number of studies on somatic embryogenesis of $P$. ginseng and P. quinquefolius (Chang, Hsing, 1980; Choi et al., 1982; Shoyama et al., 1988; Lee et al., 1990; Arya et al., 1991; Kishira et al., 1992; Jiu 1992; Arya et al., 1993; Benkrima et al., 1994; Wang, 1990; Tirajoh, Punja, 1994; Nhut et al., 2011). However, to the best of our knowledge, no report on plant regeneration via somatic embryogenesis of $P$. vietnamensis has been published.

The aim of the current study was to create an in vitro protocol for somatic embryogenesis of $P$. vietnamensis from callus cultures of tTCL.

\section{MATERIAL AND METHODS}

\section{Callus induction}

Vietnamese ginseng plants grown for three months on MS (Murashige, Skoog 1962) medium supplemented with $2.0 \mathrm{mg}^{-1} \mathrm{BA}$, and $1.0 \mathrm{mg} \mathrm{l}^{-1}$ NAA (Chien et al., 2011) were used as the source of explants (Fig. 1a). The selected plants were vitrification-free with healthy leaves and shoots. tTCLs of $1 \mathrm{~mm}$ in width were cut from in vitro leaves as initial explants and used for callus induction. Plant growth regulators (PGRs) including NAA, 2,4-D, BA and TDZ were added separately and in combination into culture media for different experiments.

\section{Callus proliferation}

Calli formation stage were cultured in MS media supplemented with $0.2 \mathrm{mg}^{-1} \mathrm{TDZ}$ and different concentrations $\mathrm{mg}^{-1}$ of the auxins 2,4-D, indole-3butyric acid (IBA) and NAA with different concentrations $\left(0.5 ; 1.0 ; 2.0 ; 3.0\right.$; and $\left.5.0 \mathrm{mg} \mathrm{l}^{-1}\right)$ in a 16 hours/day photoperiod. After 8 weeks of culture, the white calli were used as primary explants to establish embryogenic cultures.

\section{Embryogenesis}

White calli derived from in vitro leaves were cut into small pieces $(1.0 \times 1.0 \mathrm{~cm}$ dimension $)$ and placed on MS media containing $1.0 \mathrm{mg} \mathrm{l}^{-1} 2,4-\mathrm{D}, 0.5$ $\mathrm{mg}^{-1} \mathrm{NAA}$ and TDZ at various concentrations $\left(0.01 ; 0.1 ; 0.2\right.$; and $\left.0.5 \mathrm{mg} \mathrm{l}^{-1}\right)$.

\section{Culture condition and statistical analysis}

All experiments were in triplicate and each replicate with 15 explants in five culture vessels per replicate and under environment. Morphogenesis conditions were: $25 \pm 2{ }^{\circ} \mathrm{C}, 80 \%$ relative humidity, and under regular lighting conditions with a 16-h photoperiod $(2,000-2,500$ lux $)$ or darkness.

The data obtained from the present investigation were subjected to analysis of variance (ANOVA) and Duncan Multiple Range Test (Duncan 1995) at $p$ $<0.05$ was carried out to determine differences in the means using SPSS Software package (SPSS version 16.0)

\section{RESULTS AND DISCUSSION}

\section{Callus induction}

TCL technology originated almost 30 years ago with the controlled development of various organs on tobacco pedicel (Tran Thanh Van, 1973). tTCLs have been successfully used in the micropropagation of vegetable, leguminous, and medicinal plants, including Amaranthus edulis (amaranth), Beta vulgaris (sugar beet), Brassica napus (oilseed rape), Lupinus spp. (lupin), Panax ginseng (ginseng), and Phaseolus vulgaris (common bean) (Nhut et al., 2003b); cereals and grasses, including Digitaria sanguinalis (large crabgrass), Oryza sativa (rice), Sorghum bicolor (sorghum), and Zea mays (corn) (Nhut et al., 2003a); fruits, including Musa sp. (banana), Citrus spp. (orange, lemon, mandarin), Poncirus trifoliata (trifoliate orange), Cocos nucifera (coconut palm), Garcinia mangostana (mangosteen), Lycopersicon esculentum (tomato) (Nhut et al., 2003c); woody plants, including Bambusa spp. And Dendrocalamus spp. (bamboo), Manihot esculenta (cassava), Pinus radiata (Monterey pine), Paulownia fortunei (paulownia), Populus spp. (poplar), Pseudotsuga manziesii and Sequoiadendron spp. (conifers), Garcinia mangostana (garcinia/kokum), and Rosa spp. (rose) (Nhut et al., 2003c; 2003d).

The tTCls have also been successfully applied to Lilium longiflorum (Bui et al., 1999) or Oryza sativa L. (Nhut et al., 2000). This culture system proved to be more efficient than other in vitro culture methods with regard to the total output of plantlets in several plant species (Lakshmanan et al., 1995). In order to obtain rapid plant regeneration, the tTCL culture method was exploited for somatic embryogenesis from leaf derivedcallus of $P$. vietnamensis $\mathrm{Ha}$ et Grushv. 
Tạp chí Công nghệ Sinh học 14(1): 63-73, 2016

Table 1. Effect of PGRs on the callogenesis of $P$. vietnamensis leaf tTCLs after 8 weeks of culture under 16-h photoperiod.

\begin{tabular}{|c|c|c|c|c|c|}
\hline \multicolumn{4}{|c|}{ PGRs $\left(\mathrm{mg} \mathrm{l}^{-1}\right)$} & \multirow{2}{*}{ Callogenesis (\%) } & \multirow{2}{*}{ Comments on callus appearance } \\
\hline TDZ & BA & 2,4-D & NAA & & \\
\hline- & - & - & - & $0.0^{e_{*}}$ & Necrosis \\
\hline 0.01 & - & - & - & $0.0^{\mathrm{e}}$ & Necrosis \\
\hline 0.05 & - & - & - & $0.0^{\mathrm{e}}$ & Necrosis \\
\hline 0.10 & - & - & - & $0.0^{\mathrm{e}}$ & Necrosis \\
\hline 0.20 & - & - & - & $0.0^{\mathrm{e}}$ & Necrosis \\
\hline 0.50 & - & - & - & $0.0^{\mathrm{e}}$ & Necrosis \\
\hline 1.00 & - & - & - & $0.0^{\mathrm{e}}$ & Necrosis \\
\hline - & 0.1 & - & - & $0.0^{\mathrm{e}}$ & Necrosis \\
\hline - & 0.2 & - & - & $0.0^{\mathrm{e}}$ & Necrosis \\
\hline - & 0.5 & - & - & $0.0^{\mathrm{e}}$ & Necrosis \\
\hline- & 1.0 & - & - & $0.0^{\mathrm{e}}$ & Necrosis \\
\hline- & 2.0 & - & - & $0.0^{\mathrm{e}}$ & Necrosis \\
\hline- & - & 0.1 & - & $0.0^{\mathrm{e}}$ & Necrosis \\
\hline- & - & 0.2 & - & $6.7^{\mathrm{d}}$ & Small, brownish yellow, hard, and very few in number \\
\hline - & - & 0.5 & - & $13.3^{c}$ & Transparent white, and soft \\
\hline- & - & 1.0 & - & $46.7^{\mathrm{a}}$ & Milk white, yellow, and friable \\
\hline- & - & 2.0 & - & $40.0^{b}$ & Transparent yellow, and soft \\
\hline- & - & - & 0.1 & $0.0^{\mathrm{e}}$ & Necrosis \\
\hline- & - & - & 0.2 & $0.0^{\mathrm{e}}$ & Necrosis \\
\hline- & - & - & 0.5 & $0.0^{\mathrm{e}}$ & No callogenesis \\
\hline- & - & - & 1.0 & $40.0^{\mathrm{b}}$ & Brownish red, and very few in number \\
\hline- & - & - & 2.0 & $40.0^{b}$ & Brownish red, hard, and very few in number \\
\hline
\end{tabular}

Different letters $\left(^{*}\right)$ in the same column indicate significantly different means using Duncan's test $(p<0.05)$.

Table 2. Effect of PGRs on the callogenesis of $P$. vietnamensis leaf tTCLs after 8 weeks of culture under total darkness.

\begin{tabular}{llllll}
\hline & \multicolumn{2}{c}{ PGRs $\left(\mathbf{m g ~ I}^{-1}\right)$} & & \multirow{2}{*}{ Callogenesis $(\%)$} & Comments on callus appearance \\
\hline TDZ & BA & $\mathbf{2 , 4 - D}$ & NAA & & Necrosis \\
\hline- & - & - & - & $0.0^{e^{*}}$ & Necrosis \\
\hline 0.01 & - & - & - & $0.0^{\mathrm{e}}$ & Necrosis \\
0.05 & - & - & - & $0.0^{\mathrm{e}}$ & Necrosis \\
0.20 & - & - & - & $0.0^{\mathrm{e}}$ & Necrosis \\
0.50 & - & - & - & $0.0^{\mathrm{e}}$ & Necrosis \\
1.00 & - & - & - & $0.0^{\mathrm{e}}$ & Necrosis \\
- & - & - & - & $0.0^{\mathrm{e}}$ & Necrosis \\
- & 0.1 & - & - & $0.0^{\mathrm{e}}$ & Necrosis \\
- & 0.2 & - & - & $0.0^{\mathrm{e}}$ & Necrosis \\
- & 0.5 & - & - & $0.0^{\mathrm{e}}$ & Necrosis \\
- & 1.0 & - & - & $0.0^{\mathrm{e}}$ & Necrosis \\
- & 2.0 & - & - & $0.0^{\mathrm{e}}$ & Necrosis \\
- & - & 0.1 & - & $0.0^{\mathrm{e}}$ & No callogenesis \\
- & - & 0.2 & - & $0.0^{\mathrm{e}}$ & Transparent white, soft, and very few in number \\
- & - & 0.5 & - & $13.3^{\mathrm{d}}$ & Milk white, yellow, and soft \\
- & - & 1.0 & - & $33.3^{\mathrm{c}}$ & Milk-, transparent-white, and friable \\
- & - & 2.0 & - & $66.7^{\mathrm{a}}$ & No callogenesis \\
- & - & - & 0.1 & $0.0^{\mathrm{e}}$ & No callogenesis \\
- & - & - & 0.2 & $0.0^{\mathrm{e}}$ & No callogenesis \\
- & - & - & 0.5 & $0.0^{\mathrm{e}}$ & Brownish yellow, hard, and few in number \\
- & - & - & 1.0 & $46.7^{\mathrm{b}}$ & Brownish yellow, hard, and few in number \\
\hline
\end{tabular}

Different letters $\left(^{*}\right)$ in the same column indicate significantly different means using Duncan's test $(p<0.05)$. 
Explants from $P$. vietnamensis leaf tTCL explants were necrotic when cultured on PGR-free medium and media containing different concentrations of TDZ (0.01-1.0 $\left.\mathrm{mg}^{-1}\right)$ or BA (0.1$\left.2.0 \mathrm{mg} \mathrm{l}^{-1}\right)$ under either $16-\mathrm{h}$ photoperiod or total darkness. tTCLs cultured on media supplemented with different concentrations of 2,4-D (0.2-2.0 $\mathrm{mg} \mathrm{l}^{-}$ $\left.{ }^{1}\right)$ and NAA (1.0-2.0 $\left.\mathrm{mg} \mathrm{l}^{-1}\right)$ resulted in callogenesis stemming from the edges of explants (Table 1,2).

Soft friable and hard non-friable calli, were obtained on media supplemented with 2,4-D and NAA, respectively. The highest rate of callogenesis was obtained on medim supplemented with $2.0 \mathrm{mg}$ $1^{-1} 2,4-\mathrm{D}$ under total darkness $(66.7 \%) .2,4-\mathrm{D}$ is usually the most effective auxin for callus induction of species belonging to the genus Panax (Choi et al., 1994). Our result also support the conclusion that in the present study, after 8 weeks of culture, 2,4-D was the most effective PGR at promoting callus induction. NAA also induced callus formation while media containing TDZ and BA resulted in necrotic explants.

After 8 weeks of culture, under both 16-h photoperiod and total darkness $P$. vietnamensis leaf tTCL explants regardless under light or dark conditons cultured on media supplemented with 2,4$\mathrm{D}$ in combination with BA induced callus formation. Initial callus tissue emerged from the edges of explants followed by the surface. 16-h photoperiod callogenesis rates were similar to those under total darkness, and six out of eighteen treatments gave callogenesis rate of $100 \%$ (Table 3, 4).

Table 3. Effect of 2,4-D and BA on the callogenesis of $P$. vietnamensis leaf tTCLs under 16-h photoperiod.

\begin{tabular}{|c|c|c|c|}
\hline \multicolumn{2}{|c|}{ PGRs (mg l $\left.{ }^{-1}\right)$} & \multirow{2}{*}{ Callogenesis (\%) } & \multirow{2}{*}{ Callus charateristics } \\
\hline 2,4-D & BA & & \\
\hline 1.0 & 0.1 & $100.0^{a *}$ & Greenish white, and hard \\
\hline 1.0 & 0.2 & $100.0^{\mathrm{a}}$ & Greenish yellow, and hard \\
\hline 1.0 & 0.5 & $93.3^{b}$ & Milk white, yellow, and friable \\
\hline 1.0 & 1.0 & $93.3^{\mathrm{b}}$ & Greenish yellow, yellow, hard, and few in number \\
\hline 1.0 & 2.0 & $90.0^{\mathrm{b}}$ & Bright yellow, friable, and few in number \\
\hline 0.1 & 1.0 & $46.7^{\mathrm{e}}$ & Brownish yellow, and very few in number \\
\hline 0.2 & 1.0 & $60.0^{d}$ & Green, brownish yellow, hard, and very few in number \\
\hline 0.5 & 1.0 & $80.0^{c}$ & Brownish yellow, hard, and few in number \\
\hline 2.0 & 1.0 & $100.0^{\mathrm{a}}$ & Milk white, yellow, and friable \\
\hline
\end{tabular}

Different letters $\left(^{*}\right)$ in the same column indicate significantly different means using Duncan's test $(p<0.05)$.

Table 4. Combinatorial effect of 2,4-D and BA on the callogenesis of $P$. vietnamensis leaf tTCLs under total darkness.

\begin{tabular}{|c|c|c|c|}
\hline \multicolumn{2}{|c|}{ PGRs $\left(\mathrm{mg} \mathrm{l}^{-1}\right)$} & \multirow{2}{*}{ Callogenesis (\%) } & \multirow{2}{*}{ Callus charateristics } \\
\hline 2,4-D & BA & & \\
\hline 1.0 & 0.1 & $90.0^{\mathrm{b}_{*}}$ & Milk white, yellow, and friable \\
\hline 1.0 & 0.2 & $100.0^{\mathrm{a}}$ & Milk white, and friable \\
\hline 1.0 & 0.5 & $100.0^{\mathrm{a}}$ & Milk-, transparent-white, and friable \\
\hline 1.0 & 1.0 & $100.0^{\mathrm{a}}$ & Milk-, transparent-white, and friable \\
\hline 1.0 & 2.0 & $93.3^{b}$ & Brownish yellow, soft, and few in number \\
\hline 0.1 & 1.0 & $73.3^{d}$ & Brownish yellow, hard, and few in number \\
\hline 0.2 & 1.0 & $80.0^{c}$ & Brownish yellow, hard, and few in number \\
\hline 0.5 & 1.0 & $93.3^{\mathrm{b}}$ & Milk-, transparent-white, and friable \\
\hline 2.0 & 1.0 & $93.3^{b}$ & Small, white, brownish red, and soft \\
\hline
\end{tabular}

Different letters $\left(^{*}\right)$ in the same column indicate significantly different means using Duncan's test $(p<0.05)$. 
Among them, the maximum number of callus induction was achieved from explants cultured on media supplemented with $1.0 \mathrm{mg} \mathrm{l}^{-1}$ 2,4-D and 0.2 $\mathrm{mg} \mathrm{l}^{-1} \mathrm{BA}$ under 16-h photoperiod (data not show). Explants cultured under 16-h photoperiod induced green hard calli, while milk, transparent-white and brownish yellow friable calli were observed when explants were maintained under dark conditions.

Eleven of the eighteen media treatments supplemented with $1.0 \mathrm{mg} \mathrm{l}^{-1} 2,4-\mathrm{D}$ in combination with various concentrations of TDZ (0.01-1.0 $\left.\mathrm{mg} \mathrm{l}^{-1}\right)$ under 16-h photoperiod, and in the darkness with various concentrations of TDZ $\left(0.01-0.5 \mathrm{mg} \mathrm{l}^{-1}\right)$ gave callogenesis rates of $100 \%$ (Table 5, 6).

Table 5. Combinatorial effect of 2,4-D and TDZ on the callogenesis of $P$. vietnamensis leaf tTCLs under 16-h photoperiod.

\begin{tabular}{llll}
\hline & PGRs $\left(\mathbf{m g ~ l}^{-1}\right)$ & Callogenesis $(\%)$ & Comments on callus appearance \\
\hline 2,4-D & TDZ & $100.0^{\mathrm{a}_{*}}$ & White, yellow, and friable \\
\hline 1.0 & 0.01 & $100.0^{\mathrm{a}}$ & Greenish white, brownish yellow, and hard \\
1.0 & 0.05 & $100.0^{\mathrm{a}}$ & Greenish white, reddish yellow, and hard \\
1.0 & 0.10 & $100.0^{\mathrm{a}}$ & Greenish white, yellow, soft, and few in number \\
1.0 & 0.20 & $100.0^{\mathrm{a}}$ & Greenish white, reddish yellow, hard, and few in number \\
1.0 & 0.50 & $100.0^{\mathrm{a}}$ & White, brownish yellow, and friable \\
0.1 & 1.00 & $80.0^{\mathrm{b}}$ & White and friable, green and hard, and few in number \\
0.2 & 0.20 & $80.0^{\mathrm{b}}$ & Green, hard, and few in number \\
0.5 & 0.20 & $100.0^{\mathrm{a}}$ & White, brown, and friable \\
2.0 & 0.20 & $73.3^{\mathrm{c}}$ & Greenish white, brownish yellow, and soft \\
\hline
\end{tabular}

Different letters $\left(^{*}\right)$ in the same column indicate significantly different means using Duncan's test $(p<0.05)$.

Table 6. Combinatorial effect of 2,4-D and TDZ on the callogenesis of $P$. vietnamensis leaf tTCLs under total darkness.

\begin{tabular}{lcll}
\hline & PGRs $\left(\mathbf{m g ~ l}^{-1}\right)$ & Callogenesis $(\%)$ & Comments on callus appearance \\
\cline { 1 - 3 } 2,4-D & TDZ & $100.0^{\mathrm{a} *}$ & Brownish yellow, and friable \\
1.0 & 0.01 & $100.0^{\mathrm{a}}$ & Milk white, yellow, and friable \\
1.0 & 0.05 & $100.0^{\mathrm{a}}$ & Milk white, and friable \\
1.0 & 0.10 & $100.0^{\mathrm{a}}$ & White, brownish yellow, and few in number \\
1.0 & 0.20 & $100.0^{\mathrm{a}}$ & Milk-, transparent-white, and friable \\
1.0 & 0.50 & $86.7^{\mathrm{c}}$ & Milk white, brownish yellow, soft, and few in number \\
1.0 & 1.00 & $80.0^{\mathrm{d}}$ & Transparent white, brown, soft, and few in number \\
0.1 & 0.20 & $93.3^{\mathrm{b}}$ & White, brown, and soft \\
0.2 & 0.20 & $93.3^{\mathrm{b}}$ & Milk white, brownish yellow, friable, and few in number \\
0.5 & 0.20 & $0.0^{\mathrm{e}}$ & Necrosis \\
2.0 & 0.20 & & \\
\hline
\end{tabular}

Different letters $\left(^{*}\right)$ in the same column indicate significantly different means using Duncan's test $(p<0.05)$.

In comparison with media containing 2,4-D and BA, media supplemented with 2,4-D and TDZ promoted greater callus induction (data not show). Darkness was as suitable as light for callogenesis, however calli produced under $16-\mathrm{h}$ photoperiod were green and hard, while explants they were white, yellow and friable calli in the darkness. Under total darkness, medium containing $1.0 \mathrm{mg} \mathrm{l}^{-1} 2,4-\mathrm{D}$ and $0.1 \mathrm{mg} \mathrm{l}^{-1} \mathrm{TDZ}$ yielded milk white friable calli emerging from 
the edges (Fig 1b), and was the most suitable for callogenesis with the maximum callus induction (data not show).

NAA combined with BA was less effective at inducing callogenesis compared with 2,4-D and BA or 2,4-D and TDZ. Explants were necrotic in six of eighteen treatments, and callogenesis was not observed in two other treatments even though explants were still green (Table 7,8).

Table 7. Combinatorial effect of NAA and BA on the callogenesis of $P$. vietnamensis leaf tTCLs under 16-h photoperiod.

\begin{tabular}{|c|c|c|c|}
\hline \multicolumn{2}{|c|}{ PGRs (mg l' $\left.{ }^{-1}\right)$} & \multirow{2}{*}{ Callogenesis (\%) } & \multirow{2}{*}{ Comments on callus appearance } \\
\hline NAA & BA & & \\
\hline 1.0 & 0.1 & $13.3^{\mathrm{c}_{*}}$ & Green, hard, and very few in number \\
\hline 1.0 & 0.2 & $0.0^{\mathrm{d}}$ & Necrosis \\
\hline 1.0 & 0.5 & $0.0^{\mathrm{d}}$ & Necrosis \\
\hline 1.0 & 1.0 & $33.3^{b}$ & Brown, and very few in number \\
\hline 1.0 & 2.0 & $0.0^{\mathrm{d}}$ & No callogenesis \\
\hline 0.1 & 1.0 & $0.0^{\mathrm{d}}$ & Necrosis \\
\hline 0.2 & 1.0 & $0.0^{\mathrm{d}}$ & Necrosis \\
\hline 0.5 & 1.0 & $0.0^{\mathrm{d}}$ & Necrosis \\
\hline 2.0 & 1.0 & $60.0^{\mathrm{a}}$ & Green, hard, and very few in number \\
\hline
\end{tabular}

Different letters $\left({ }^{*}\right)$ in the same column indicate significantly different means using Duncan's test $(p<0.05)$.

Table 8. Combinatorial effect of NAA and BA on the callogenesis of $P$. vietnamensis leaf tTCLs under total darkness.

\begin{tabular}{llll}
\hline \multicolumn{2}{c}{ PGRs $\left(\mathbf{m g ~ l}^{-1}\right)$} & \multirow{2}{*}{ Callogenesis (\%) } & Comments on callus appearance \\
\cline { 1 - 2 } NAA & BA & & \\
\hline 1.0 & 0.1 & $40.0^{\mathrm{d} *}$ & Transparent white, brownish yellow, soft, and few in number \\
1.0 & 0.2 & $33.3^{\mathrm{e}}$ & Brown, and very few in number \\
1.0 & 0.5 & $53.3^{\mathrm{c}}$ & Brown, hard, and few in number \\
1.0 & 1.0 & $93.3^{\mathrm{b}}$ & White, brownish yellow, and soft \\
1.0 & 2.0 & $13.3^{\mathrm{f}}$ & Brownish yellow, and few in number \\
0.1 & 1.0 & $0.0^{\mathrm{g}}$ & No callogenesis \\
0.2 & 1.0 & $0.0^{\mathrm{g}}$ & Necrosis \\
0.5 & 1.0 & $90.0^{\mathrm{b}}$ & Greenish white, brownish yellow, hard, and few in number \\
2.0 & 1.0 & $100.0^{\mathrm{a}}$ & White, brown, and soft \\
\hline
\end{tabular}

Different letters $\left(^{*}\right)$ in the same column indicate significantly different means using Duncan's test $(p<0.05)$.

Total darkness was more suitable to callus formation than the 16-h photoperiod (Table 7,8), and explants cultured on media supplemented with $2.0 \mathrm{mg}^{-1}$ NAA and $1.0 \mathrm{mg} \mathrm{l}^{-1} \mathrm{BA}$ under total darkness gave the best rate of callogenesis $(100 \%)$, while $60 \%$ was achieved on the same media formulation under 16-h photoperiod. Calli emerged from the edges of explants and were few in number.

The rate of callogenesis was increased when using one auxin in combination with one cytokinin, and this was apparent in media supplemented with 2,4-D in combination with TDZ, which was the most suitable combination for callus formation. This result is consistent with callus formation in $P$. ginseng and $P$. quinquefolius, which was most successful on MS media supplemented with 2,4-D in combination with kinetin (KIN) or with BA (Furuya et al., 1986; Wang 1990; Jiu, 1992).

Previous studies reported that dark conditions are the most suitable for callogenesis in species 
belonging to the genus Panax (Furuya et al., 1986; Wang 1990; Choi et al., 1994; Tirajoh, Punja 1994). In this study, explants cultivated under dark and light conditions induced callus formation. No significant difference $(\mathrm{p}>0.05)$ in the rate of callus initiation was observed in cultures incubated under total darkness compared with 16-h photoperiod. The calli formed under total darkness were milk, transparentwhite to white, and brownish yellow to brown in color while calli induced under $16-\mathrm{h}$ photoperiod were white to greenish white and green, and yellow to brownish yellow in color. Under dark conditions, two types of calli were formed: hard calli, and soft and friable calli whereas the 16 -h photoperiod conditions yielded mostly hard and friable calli.

\section{Callus proliferation}

Auxin/cytokinin ratio is important for growth of cells in vitro (Rita et al., 1991). In the present work, three sets of treatments were explored to study the combined effect of auxins and cytokinins on callus proliferation. Calli derived from leaf tTCLs of Vietnamese ginseng were sub-cultured on media supplemented with 2,4-D, IBA and NAA at either
$0.5,1.0,2.0,3.0$ or $5.0 \mathrm{mg}^{-1}$ in combination with TDZ at $0.2 \mathrm{mg}^{-1}$. Callus pieces continued to proliferate on all tested media and produced fresh biomass between 0.5 to $0.8 \mathrm{~g}$ and a dry biomass between 0.035 to $0.066 \mathrm{~g}$ from the initial inoculum of approximately $0.2 \mathrm{~g}$ callus after 4 weeks of culture (Table 9).

Most of the media containing 2,4-D stimulated higher callus induction than those with IBA or NAA (Table 9). Callus exhibited good growth on the medium supplemented with $1.0 \mathrm{mg} \mathrm{l}^{-1}$ 2,4-D with approximately 4-fold fresh weight increase after 4 weeks of culture (Table 9). The higher concentration of 2,4-D (5 $\left.\mathrm{mg}^{-1}\right)$ was not suitable for callus growth.

Our results also showed that the combination of TDZ and auxins, especially 2,4-D, significantly improved the callus growth of $P$. vietnamensis. TDZ is classified as a type of cytokinin; however, it has shown both auxin and cytokinin like effects to induce and maintain a number of biological events in cells (Guo et al., 2011). It is thought that TDZ enhances the accumulation and transport of auxin in cultured tissues.

Table 9. Effect of the combinations of $0.2 \mathrm{mg} \mathrm{I}^{-1}$ TDZ and 2,4-D, IBA or NAA on callus proliferation of $P$. vietnamensis after 4 weeks of culture.

\begin{tabular}{|c|c|c|c|c|}
\hline \multicolumn{3}{|c|}{ PGRs (mg l' $\left.{ }^{-1}\right)$} & \multirow{2}{*}{ Final fresh weight - FW $(\mathrm{mg})$} & \multirow{2}{*}{ Dry weight - DW (mg } \\
\hline 2,4-D & IBA & NAA & & \\
\hline- & - & - & $424^{\mathrm{j} *}$ & $31.4^{\mathrm{h}}$ \\
\hline 0.5 & - & - & $584^{\text {cde }}$ & $43.3^{\mathrm{ef}}$ \\
\hline 1.0 & - & - & $809^{a}$ & $66.2^{\mathrm{a}}$ \\
\hline 2.0 & - & - & $711^{\mathrm{b}}$ & $52.4^{\mathrm{b}}$ \\
\hline 3.0 & - & - & $508^{\mathrm{fghi}}$ & $36.6^{\mathrm{g}}$ \\
\hline 5.0 & - & - & $493^{\mathrm{ghi}}$ & $34.6^{\text {gh }}$ \\
\hline- & 0.5 & - & $474^{\mathrm{ij}}$ & $45.6^{\text {cde }}$ \\
\hline- & 1.0 & - & $532^{\text {efgh }}$ & $48.6^{\mathrm{bcd}}$ \\
\hline- & 2.0 & - & $631^{\mathrm{c}}$ & $49.5^{\mathrm{bc}}$ \\
\hline- & 3.0 & - & $552^{\text {def }}$ & $41.1^{\mathrm{f}}$ \\
\hline- & 5.0 & - & $531^{\text {efgh }}$ & $35.3^{\mathrm{gh}}$ \\
\hline- & - & 0.5 & $485^{\mathrm{hi}}$ & $41.2^{f}$ \\
\hline- & - & 1.0 & $548^{\text {defg }}$ & $45.0^{\text {def }}$ \\
\hline- & - & 2.0 & $588^{\mathrm{cd}}$ & $46.6^{\mathrm{cde}}$ \\
\hline- & - & 3.0 & $602^{\text {cd }}$ & $45.7^{\text {cde }}$ \\
\hline- & - & 5.0 & $720^{b}$ & $51.6^{b}$ \\
\hline
\end{tabular}

Initial fresh weight was $205 \pm 8 \mathrm{mg}$. Different letters $\left(^{*}\right)$ in the same column indicate significantly different means using Duncan's test $(p<0.05)$. 
Vu Thi Hien et al.
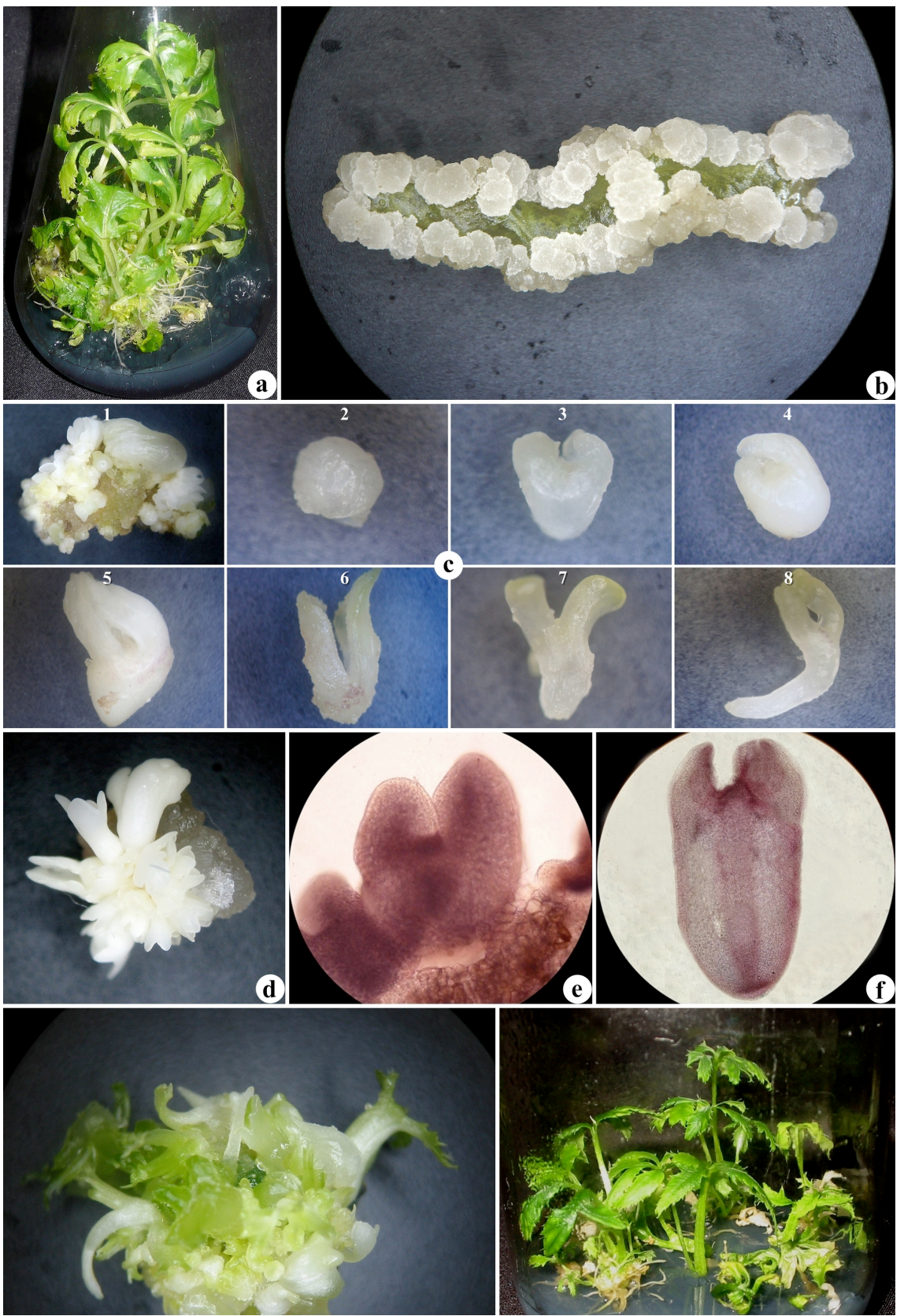

Figure 1. Somatic embryogenesis from leaf tTCLs derived-callus of $P$. vietnamensis. a 3-month-old in vitro plantlets, b Callus formation, c Somatic embryogenesis (1 Embryo cluster, 2 Global shape, 3, 4, 5 Heart shape, 6 Cotyledonary, 7, 8 Embryos with roots), $\mathbf{d}$ Embryo cluster, e, f Embryo structure, $\mathbf{g}, \mathbf{h}$ Embryo germinating.

\section{Embryogenesis}

PGRs are required for induction of embryogenesis; and the most commonly-used PGRs for this purpose are 2,4-D, dicamba and picloram
(Roostika, Mariska, 2003). Investigations on somatic embryogenesis of Panax species showed that synthetic auxins added to the culture media had an important role. Among all the growth regulators 
evaluated, 2,4-D gave the highest frequency of callus and somatic embryo formation in Panax ginseng (Arya et al., 1993; Chang, Hsing 1980; Shoyama et al., 1987; Zhong, Zhong 1992).

Somatic embryogenesis could be further improved when other PGRs were added to medium containing 2,4-D, such as KIN (Choi et al., 1984; Furuya et al., 1986; Lee et al., 1989) or NAA (Wang et al., 1999). In the present study, the combinations of 2,4-D $\left(1.0 \mathrm{mg} \mathrm{l}^{-1}\right)$, NAA $\left(0.5 \mathrm{mg} \mathrm{l}^{-}\right.$ $\left.{ }^{1}\right)$ and TDZ at various concentrations were tested. Table 10 summarizes the response, which shows that $0.2 \mathrm{mg} \mathrm{l}^{-1} \mathrm{TDZ}$ in combination with $1.0 \mathrm{mg} .1^{-1}$ 2,4-D and $0.5 \mathrm{mg} . \mathrm{l}^{-1} \mathrm{NAA}$ had a maximum effect on somatic embryogenesis of $P$. vietnamensis. On this medium, small globular, glossy somatic embryos started to appear from the upper surface of callus mass (Fig. 1c, 1d, 1e, 1f) and these embryos developed into normal plantlets on PGR-free MS medium (Fig. 1g, 1h).

Table 10. Effect of $1.0 \mathrm{mg} \mathrm{l}^{-1}$ 2,4-D in combination with $0.5 \mathrm{mg} \mathrm{l}^{-1} \mathrm{NAA}$ and various concentration of TDZ on somatic embryogenesis of $P$. vietnamensis.

\begin{tabular}{llll}
\hline TDZ $\left(\mathrm{mg} \mathrm{l}^{-1}\right)$ & Embryogenesis (\%) & Number of embryos/explant & $\begin{array}{l}\text { Stages of embryos } \\
\text { development }\end{array}$ \\
\hline- & $17.7^{\mathrm{c} *}$ & $12^{\mathrm{d}}$ & Globular \\
0.01 & $21.0^{\mathrm{c}}$ & $16^{\mathrm{c}}$ & Globular \\
0.1 & $40.0^{\mathrm{b}}$ & $21^{\mathrm{b}}$ & Globular, heart shape \\
0.2 & $35^{\mathrm{a}}$ & Globular, heart shape \\
0.5 & $53.3^{\mathrm{a}}$ & $17^{\mathrm{c}}$ & Globular \\
\hline
\end{tabular}

Different letters $\left(^{*}\right)$ in the same column indicate significantly different means using Duncan's test $(p<0.05)$.

\section{CONCLUSION}

In summary, the present study outlines a protocol for somatic embryogenesis of $P$. vietnamensis Ha et Grushv. from leaf tTCL explants. Our results showed that calli were successfully induced from the leaf tTCL explants cultured on medium supplemented with either 2,4-D and BA or 2,4-D and TDZ. Callogenesis was observed under both light and dark conditions. The best results were obtained with MS media supplemented with $1.0 \mathrm{mg}$ $\mathrm{l}^{-1}$ 2,4-D and $0.1 \mathrm{mg} \mathrm{l}^{-1}$ TDZ under total darkness. Callus proliferation could be obtained on MS media containing $1.0 \mathrm{mg} \mathrm{l}^{-1}$ 2,4-D and $0.2 \mathrm{mg} \mathrm{l}^{-1}$ TDZ. These calli were sub-cultured onto MS media supplemented with $1.0 \mathrm{mg} \mathrm{l}^{-1}$ 2,4-D, $0.5 \mathrm{mg} \mathrm{l}^{-1} \mathrm{NAA}$ and $0.2 \mathrm{mg} \mathrm{l}^{-1} \mathrm{TDZ}$ to induce somatic embryogenesis. This technique could be used as a tool for large scale micropropagation of $P$. vietnamensis.

Acknowledgments: The authors would like to thank the Department of Application and Development of Technology (Vietnam Academy of Science and Technology) for the financial support.

\section{REFERENCES}

Arya S, Arya ID, Eriksson T (1993) Rapid multiplication of adventitious somatic embryos of Panax ginseng. Plant Cell TissOrg Cult 34: 157-162.

Arya S, Liu JR, Eriksson T (1991) Plant regeneration from protoplasts of Panax ginseng (C.A. Meyer) through somatic embryogenesis. Plant Cell Rep 10: 277-281.

Benkrima L, Sun LH, Sain S, Zhu J, Ma YC, Kont C, Plaut-Carcasson YY (1994) Adventitious somatic embryogenesis, plant regeneration and in vitro flowering of ginseng (Panax ginseng C.A. Meyer). Proc Interl Ginseng Conf, Vancouver, p 513.

Bui VL, Nhut DT, Tran Thanh Van K (1999) Plant production via shoot regeneration from thin cell layer pseudo-bulblets explants of Lilium longiflorum in vitro. Comptes Rendus de l'Académie des Scien 322: 303-310.

Chang WC, Hsing YI (1980) Plant regeneration through somatic embryogenesis in root-derived callus of ginseng (Panax ginseng C. A. Meyer). Theo Appl Gen 57: 133-135.

Chien HX, Tai NT, Truc NB, Tinh TX, Thao LB, Luan TC, Nhut DT (2011) Effect of some factors to in vitro microrhizome formation (Panax vietnamensis $\mathrm{Ha}$ et Grushv.) and determination of plantlet saponin content in Ngoc Linh mountain. J Biotech Vietnam 8(3B): 1211-1219.

Choi KT, Lee CH, Ahn IO, Lee JH, Park JC (1994) Characteristics of the growth and ginsenosides in the suspension-cultured cells of Korean ginseng (Panax ginseng C.A. Meyer). Proc Interl Ginseng Conf, Vancouver, pp: 259-268. 
Choi KT, Yang DC, Kim NW, Ahn IO (1984) Redifferentiation from tissue culture and isolation of viable protoplasts in Panax ginseng C. A. Meyer. Proc 4th Inter Ginseng Symp, Korea, pp: 1-11.

Choi KT, Kim MW, Shin HS (1982) Root and shoot formation from callus and leaflet cultures of ginseng (Panax ginseng C.A. Meyer). In Fujiwara A, ed., Plant Tissue Culture: Proceedings of the 5th International Congress of Plant Tissue and Cell Culture, Tokyo, pp: 171-172.

Duc NM, Kasai R, Yamasaki K, Nham NT, Tanaka O (1999) New dammarane saponins from Vietnamese ginseng. Stud Plant Scien 6: 77-82.

Duncan DB (1995) Multiple range and multiple F tests. Biometrics 11: 1-5.

Furuya T, Yoshikawa T, Ushiyama K, Oda H (1986) Formation of plantlets from callus cultures of ginseng (Panax ginseng). Experientia 42(2): 193-194.

Gonzalez AM, Cristóbal CL (1997) Anatomía y ontogenia de semillas de Helicteres Lhatzkyana (Sterculiaceae). Bonplandia 9: 287-294.

Guo B, Abbasi BH, Zeb A, Xu LL, Wei YH (2011) Thidiazuron: A multi-dimensional plant growth regulator. Afr J Biotech 10(45): 8984-9000.

Huong NTT, Matsumoto K, Kasai R, Yamasaki K, Watanabe H. 1998. In vitro antioxidant activity of Vietnamese ginseng saponin and its components. Biological and Pharmaceutical Bulletin 21: 978-981.

Jiu SY (1992) Plant regeneration from adventitious rootderived calli of ginseng (Panax ginseng C.A. Meyer). $J$ Agr Assoc China New Series 0: 41-48.

Johansen DA (1940) Plant microtechnique. McGraw-Hill Book Company, Inc., New York, p: 551.

Kishira H, Takada M, Shoyama Y (1992) Micropropagation of Panax ginseng C.A. Meyer by somatic embryos. In Hayashi M, Kano A, Goto E, eds. Proceedings of the International symposium on transplant production systems, Yokohama, Japan, 1(319): 197-202.

Konoshima T, Takasaki M, Ichiishi E, Murakami T, Tokuda H, Duc NM, Kasai R, Yamasaki K (1999) Cancer chemopreventive activity of majonoside-R2 from Vietnamese ginseng, Panax vietnamensis. Cancer Letters 147(1-2): 11-16.

Lakshmanan P, Loh CS, Goh CJ (1995) An in vitro method for rapid regeneration of a monopodial orchid hybrid Aranda Deborah using thin section culture. Plant Cell Rep 14: 510-514.

Lee HS, Lee KW, Yang SG, Jeon JH, Liu JR (1989) Plant regeneration through somatic embryogenesis from mature zygotic embryos of ginseng (Panax ginseng C. A. Meyer) and flowering of plantlets. Korean J Botany 32: 145-150.
Lee HS, Liu JR, Yang SG, Lee YH (1990) In vitro flowering of plantlets regenerated from zygotic somatic embryos of ginseng. HortScience 25(12): 1652-1654.

Luque R, Sousa HC, Kraus JE (1996) Métodos de coloracao de Roeser (1972) e Kropp (1972) visando a subtituicao do azul do astra por azul de alciao 8GS ou 8GX. Acta Bot Brasilica 10: 199-212.

Ministry of Science, Techonology and Environment (1996) Red data book of Vietnam. Plans Publ house "Science and Technics" Hanoi, p 484.

Monteiro M, Kevers C, Dommes J, Gaspar T (2002) A specific role for spermidine in the initiation phase of somatic embryogenesis in Panax ginseng C.A. Meyer. Plant Cell Tiss Org Cult 68: 225-232.

Nhut DT, Bui VL, Tran Thanh Van K (2000) Somatic embryogenesis and direct shoot regeneration of rice (Oryza sativa L.) using thin cell layer culture of apical meristematic tissue. Plant Physiol 157: 559-565.

Nhut DT, Chien HX, Truc NB, Nam NB, Tinh TX, Luan VQ, Binh NV, Hien VT, Huong TT, Nhan NCT, Thuy LNM, Nga LTM, Hien TT, Hai NT (2010) Micropropagation of Panax vietnamensis Ha et Grushv. J Biotech Vietnam 8(3B): 1211-1219.

Nhut DT, Huy NP, Luan VQ, Binh NV, Nam NB, Thuy LNM, Ha DTN, Chien HX, Huong TT, Cuong HV, Cuong LK, Hien VT (2011) Shoot regeneration and micropropagation of Panax vietnamensis Ha et Grushv. from ex vitro leaf-derived callus. Afr J Biotech 10(84): 19499-19504

Nhut DT, Teixeira da Silva JA, Bui VL, Tran Thanh Van K (2003a) Organogenesis of cereals and grasses by using thin cell layer technique. In Nhut DT, Van Le B, Tran Thanh Van K, Thorpe T, eds. Thin cell layer culture system: regeneration and transformation applications. Kluwer Academic Publishers, Dordrecht: 427-449.

Nhut DT, Teixeira da Silva JA, Bui VL, Tran Thanh Van $\mathrm{K}$ (2003b) Thin cell layer studies of vegetable, leguminous and medicinal plants. In Nhut DT, Van Le B, Tran Thanh Van K, Thorpe T, eds. Thin cell layer culture system: regeneration and transformation application. Kluwer Academic Publishers, Dordrecht: 387-425.

Nhut DT, Teixeira da Silva JA, Bui VL, Thorpe T, Tran Thanh Van K (2003c) Woody plant micropropagation and morphogenesis by thin cell layers. In Nhut DT, Van Le B, Tran Thanh Van K, Thorpe T, eds. Thin cell layer culture system: regeneration and transformation application. Kluwer Academic Publishers, Dordrecht: 473-493.

Nhut DT, Teixeira da Silva JA, Bui VL, Tran Thanh Van $\mathrm{K}$ (2003d) Thin cell layer (TCL) morphogenesis as a powerful tool in woody plant and fruit crop micropropagation and biotechnology, floral genetics and genetic transformation. In Jain SM, Ishii K, eds. 
Micropropagation of woody trees and fruits. Kluwer Academic Publishers, Dordrecht: 783-814.

Rita AT, Matthew WD, John DO, David GL, Andrew NB (1991) Activity and accumulation of cell division Promoting phenolics in tobacco tissue cultures. Plant Physiol 97: 288-297.

Roostika IT, Mariska I (2003) In vitro culture of Pineapple by organogenesis and somatic embryogenesis: Its utilization and prospect. Buletin Agro Bio 6: 34-40.

Shoyama Y, Kamura K, Nishioka I (1988) Somatic embryogenesis and clonal multiplication of Panax ginseng. Planta Medica 54: 155-156.

Tirajoh A, Punja ZK (1994) Tissue culture and Agrobacterium-mediated transformation of American ginseng (Panax quinquefolium L.). Proc Int Ginseng Conf, Vancouver, pp 144-155

Tran Thanh Van M (1973) In vitro control of de novo flower, bud, root and callus differentiation from excised epidermal tissues. Nature 246: 44-45.

Wang AS (1990) Callus induction and plant regeneration of American ginseng. HortScience 25(5): 571-572.

Wang X, Proctor JTA, Krishnaraj S, Saxena PK, Sullivan JA (1999) Rapid somatic embryogenesis and plant regeneration in American ginseng: effects of auxins and explants. J Ginseng Research 23: 148-163.

Yamasaki K (2000) Bioactive saponins in Vietnamese ginseng, Panax vietnamensis. Pharma Bio 38: 16-24.

Yobimoto K, Matsumoto K, Huong NT, Kasai R, Yamasaki K, Watanabe H (2000) Suppressive effects of vietnamese ginseng saponin and its major component majonoside-R2 on psychological stress-induced enhancement of lipid peroxidation in the mouse brain. Pharma Biochem Behavior 66(3): 661-665.

Zhong SL, Zhong SG (1992) Morphological and uhrastructural characteristics of the embryogenic callus of American ginseng. Chinese J Bot 4: 92-98.

\section{SỰ HİNH THÀNH PHÔI VÔ TÍNH TÙ MÔ SẸO CÓ NGUỒn GỐC TỬ LỚP MỎNG TẾ BẢO LÁ CẮT NGANG Ở SÂM VIẸTT NAM (PANAX VIETNAMENSIS HA ET GRUSHV.)}

Vũ Thị Hiền, Nguyễn Phúc Huy, Bùi Văn Thế Vinh, Hoàng Xuân Chiến, Hoàng Thanh Tùng, Nguyễn Bá Nam, Vũ Quốc Luận, Dương Tấn Nhựt ${ }^{凶}$

Viện Nghiên cưu khoa học Tây Nguyên, Viện Hàn lâm Khoa học và Công nghệ Việt Nam

\section{TÓM TẮT}

Đến nay, chưa có báo cáo nào công bố về sự tái sinh cây thông qua quá trình phát sinh phôi vô tính ở sâm Việt Nam. Trong nghiên cứu này, khả năng phát sinh phôi vô tính gián tiếp qua sự hình thành mô sẹo từ việc nuôi cấy mẫu lớp mỏng tế bào cắt ngang của lá (tTCL) ở sâm Việt Nam (Panax vietnamensis Ha et Grushv.) đã được tiến hành nghiên cứu. Các chất điều hòa sinh trưởng hực vật $\alpha$-naphthaleneacetic acid (NAA), 2,4dichlorophenoxyacetic acid (2,4-D), 6-benzylaminopurine (BA) và thidiazuron (TDZ) đã được bổ sung ở dạng riêng lẻ hoặc kết hợp vào môi trường nuôi cấy. Mẫu cấy bị hoại tử hoặc tỷ lệ tạo mô sẹo thấp đã được ghi nhận khi các mẫu tTCL với độ rộng $1 \mathrm{~mm}$ được nuôi cấy trên môi trường có bổ sung chỉ một chất điều hòa sinh trưởng thực vật. Trong khi, việc cảm ứng hình thành mô sẹo thành công từ các mẫu được nuôi cấy trên môi trường có bổ sung 2,4-D và $\mathrm{BA}$ hoặc 2,4-D kết hợp với TDZ. Sự hình thành mô sẹo đã được ghi nhận cả dưới điều kiện chiếu sáng và trong điều kiện tối. Tỷ lệ hình thành mô sẹo cao nhất (100\%) thu được trên môi trường Murashige và Skoog (MS) có bổ sung $1,0 \mathrm{mg} \mathrm{l}^{-1}$ 2,4-D kết hợp với $0,1 \mathrm{mg}^{-1} \mathrm{TDZ}$ trong điều kiện tối sau 8 tuần. Mô sẹo màu trắng được cắt thành những mẫu nhỏ $(1,0 \times 1,0 \mathrm{~cm})$ và cấy lên môi trường $\mathrm{MS}$ có bổ sung $1,0 \mathrm{mg} \mathrm{l}^{-1} 2,4-\mathrm{D}, 0,5 \mathrm{mg} \mathrm{l}^{-1} \mathrm{NAA}$ và TDZ ở các nồng độ khác nhau $\left(0,01 ; 0,1 ; 0,2\right.$ và $\left.0,5 \mathrm{mg} \mathrm{l}^{-1}\right)$ và sự tăng sinh mô sẹo tốt nhất đã được ghi nhận trên môi trường có bổ sung $1,0 \mathrm{mg} \mathrm{l}^{-1} 2,4-\mathrm{D}$ và $0,2 \mathrm{mg} \mathrm{l}^{-1} \mathrm{TDZ}$. Sự phát sinh phôi vô tính thành công với tỷ lệ tạo phôi $53,3 \%$ và 35 phôi/mẫu cấy đã thu được khi mô sẹo được nuôi cấy trên môi trường MS có bồ sung 1,0 $\mathrm{mg} \mathrm{l}^{-1} 2,4-\mathrm{D}, 0,5 \mathrm{mg} \mathrm{l}^{-1} \mathrm{NAA}$ and $0,2 \mathrm{mg}^{-1}$ TDZ.

Tù khóa: Mô sẹo, Panax vietnamensis, phôi vô tính, lớp mỏng tế bào

\footnotetext{
${ }^{凶}$ Author for correspondence: Tel: +84-63-3831056; Fax: +84-63-3831028; E-mail: duongtannhut@gmail.com
} 